\title{
Interactive comment on "Improving Soil Moisture Prediction of a High-Resolution Land Surface Model by Parameterising Pedotransfer Functions through Assimilation of SMAP Satellite Data" by Ewan Pinnington et al.
}

Ewan Pinnington et al.

e.pinnington@reading.ac.uk

Received and published: 7 October 2020

We thank the reviewer for their comments. Please find detailed responses in the attached pdf.

Kind Regards, 
https://hess.copernicus.org/preprints/hess-2020-303/hess-2020-303-AC2supplement.pdf

Interactive comment on Hydrol. Earth Syst. Sci. Discuss., https://doi.org/10.5194/hess-2020303, 2020. 